\title{
Long-term exposure investigating the estrogenic potency of estriol in Japanese medaka (Oryzias latipes)
}

\author{
Bingli Lei ${ }^{a}$, Jia Kang ${ }^{a}$, Yingxin Yu ${ }^{\text {a }}$, Jinmiao Zha ${ }^{b}$, Wei Li ${ }^{b}$, Zijian Wang ${ }^{\text {b, } *}$, Yipei Wang ${ }^{\text {a }}$, Yu Wen ${ }^{\text {a }}$ \\ a Institute of Environmental Pollution and Health, College of Environmental and Chemical Engineering, Shanghai University, Shanghai, 200444, China \\ b State Key Laboratory of Environmental Aquatic Chemistry, Research Center for Eco-Environmental Sciences, Chinese Academy of Sciences, Beijing 100085, China
}

\section{A R T I C L E I N F O}

Article history:

Received 24 May 2013

Received in revised form 17 October 2013

Accepted 6 November 2013

Available online 11 November 2013

\section{Keywords:}

Estriol

Estrogenic potency

Vitellogenin gene

Estrogen receptor gene

Environmentally relevant concentration

Oryzias latipes

\begin{abstract}
A B S T R A C T
The growth, development, and ER $\alpha$ and Vtg-I gene expressions of Japanese ricefish (Oryzias latipes; medaka) exposed to different concentrations of estriol (E3), including one environmentally relevant concentration, during embryo-adult life stages were evaluated. At the early life stage, fertilized eggs were exposed to 5, 50, 500, $5000 \mathrm{ng} / \mathrm{L} \mathrm{E3}$ for 15 days, and the hatched fry were exposed continuously to the same concentrations for an additional 15 days. Exposure to 500 and $5000 \mathrm{ng} / \mathrm{L} \mathrm{E3} \mathrm{resulted} \mathrm{in} \mathrm{adverse} \mathrm{effects} \mathrm{on} \mathrm{hatchability} \mathrm{and} \mathrm{time} \mathrm{to}$ hatching. At $5000 \mathrm{ng} / \mathrm{L}$, the gross abnormality rate was increased and the number of females that hatched was twice that of males. When the fish were exposed to 5-5000 ng/L E3 for further 60 days, the male hepatosomatic index (HSI) was increased at $5000 \mathrm{ng} / \mathrm{L}$. The female gonadosomatic index (GSI) was decreased at 500 and $5000 \mathrm{ng} / \mathrm{L} \mathrm{E3}$, while the male GSI at $5000 \mathrm{ng} / \mathrm{L} \mathrm{E3}$ was increased and sex reversal was also found at this concentration. Quantitative RT-PCR showed that the hepatic vitellogenin-I (Vtg-I) genes were up-regulated in females at 500 and $5000 \mathrm{ng} / \mathrm{L}$ E3 and in males at all E3 concentrations, whereas E3 did not affect estrogen receptor $\alpha(\mathrm{ER} \alpha)$ mRNA transcription. These results showed that E3 at environmental concentration of $5 \mathrm{ng} / \mathrm{L}$ has no adverse effects on growth and development of the Japanese medaka. However, in this study, if we only focused on Vtg gene change in males, E3 had strong estrogenic effects on male medaka under the conditions of these experiments.
\end{abstract}

(c) 2013 Elsevier Inc. All rights reserved.

\section{Introduction}

Steroidal estrogens can be characterized as either natural (for example, estriol [E3]) or synthetic (for example, ethinylestradiol [EE2]) based on their origin. They are a potent subset of steroid hormones and play important roles in the reproductive biology of vertebrates like fish (Lange et al., 2012). Steroidal estrogens exist widely in the aquatic environment originating mainly from domestic sewage, and the effluents from wastewater treatment plants and agriculture (Lei et al., 2009). They may cause adverse reproductive and development toxicity on fish at low concentrations (Nash et al., 2004; Zha et al., 2008; Saaristo et al., 2009). For example, Zha et al. (2008) found that $17 \alpha$-ethinylestradiol (EE2) at $1 \mathrm{ng} / \mathrm{L}$ can significantly affect the following test endpoints in the F0 generation of Chinese rare minnow (Gobiocypris rarus): deformities, reproductive parameters, plasma vitellogenin and histopathology, and EE2 at $0.2 \mathrm{ng} / \mathrm{L}$ can completely inhibit the reproduction of the F1 minnows. Nash et al. (2004) reported that life-long exposure to $5 \mathrm{ng} / \mathrm{L}$ EE2 in the F1 generation of zebrafish (Danio rerio) caused a $56 \%$ reduction in fecundity and complete population failure with no fertilization. In our previous work, we also found that $\beta$-estradiol

\footnotetext{
* Corresponding author. Tel.: +8610 62849107; fax: +861062849017. E-mail address: wangzj@rcees.ac.cn (Z.Wang).
}

17-valerate (EV) at $1 \mathrm{ng} / \mathrm{L}$ can induce feminization and affect normal development of medaka (Oryzias latipes) (Lei et al., 2013a). Several field studies have also shown that these adverse reproduction and development responses in wild fish may be due to chemicals present in aquatic environments (Van Aerle et al., 2001; Jobling et al., 2006; Lange et al., 2011; Yan et al., 2012) and are related to reproductive failure in fish (Nash et al., 2004).

Estrogens can induce biological changes by binding to the estrogen receptor (ER) (Arukwe et al., 2001). Medaka fish express least three distinct types of ER (ER $\alpha, E R \beta 1$ and ER $\beta 2)$ (Hawkins et al., 2000; Chakraborty et al., 2011). The complete estrogen receptor family identified in pseudotetraploid rainbow trout consists of two subtypes (ER $\alpha$ and ER $\beta$ ) each of which consists of two isoforms ( $\alpha 1 / \alpha 2$ and $\beta 1 / \beta 2)$, and the levels of ER $\alpha 1$ mRNA are more easily affected by estradiol (E2) and EE2 than those of other isoforms (Boyce-Derricott et al., 2009). In this study, we mainly focused on the ER $\alpha$. Vitellogenin (Vtg), a major precursor of the egg-yolk proteins in oviparous vertebrates, is usually synthesized in the liver of mature females and transported to the ovaries (Zhang et al., 2008b). In male and juvenile fish, Vtg levels generally are lower and Vtg gene is normally silent. However, it may be activated by (xeno)-estrogens (Zhang et al., 2008b). Numerous fish studies reported that potent endocrine disrupting chemicals (EDCs) such as E2 and EE2, can alter Vtg and ER $\alpha$ gene expressions in fish 
(Scholz and Gutzeit, 2000; Andreassen et al., 2005; Huang et al., 2010; Saaristo et al., 2010). For example, Andreassen et al. (2005) reported that the hepatic ER $\alpha$ gene in the eelpout (Zoarces viviparous) after exposure to E2 for 48 h was significantly up-regulated. Huang et al. (2010) found dose-dependent up-regulation of the Vtg-I gene in the liver of male medaka fish exposed to concentrations of $100 \mathrm{ng} / \mathrm{L} \mathrm{E2}$ and above for 2 weeks. In our previous studies, we also found that the levels of $\mathrm{ER} \alpha$ and Vtg-I mRNAs in the liver of medaka (O. latipes) exposed to EV and estrone (E1) can be altered (Lei et al., 2013a;b). Therefore, Vtg and ER genes have been widely used as marker genes to evaluate the effects of EDCs on fish (Zhang et al., 2008a; Chen et al., 2010; Sellin et al., 2010).

Estriol (E3) is one form of estrogen metabolized from E2 through E1 in the ovaries of women and E3 is the principal estrogen produced by the placenta during pregnancy when it achieves even a 1000-fold increase (Lappano et al., 2010). However, E3 is assumed to be less potent than E2 and E1 at similar concentrations. For example, Luo et al. (2011) utilized two-hybrid yeast bioassay to determine the relative potencies (RPs) of estrogens and found that the RPs of E3 and E1 relative to E2 were 0.0049 and 0.053 , respectively. Lange et al. (2012) used in vitro $\mathrm{ER} \alpha$ activation assays for a range of fish species to determine estrogenic potencies. It was found that higher concentrations of E3 (1.62-9.55 nM) were necessary for the transcription of fish $\mathrm{ER} \alpha$ compared to the induction by E2 (0.18-0.36 nM). Several studies have determined the estrogenic effects of E3 using in vitro assays (Tollefsen et al., 2003; Denny et al., 2005; Luo et al., 2011; Lange et al., 2012). However, few studies reported the estrogenic effect of E3 on fish using in vivo assays, and in these studies, only early life stage of fish was exposed to E3, or only single test endpoint such as intersex (i.e., testis-ova) in fish was investigated (Metcalfe et al., 2001; Holbech et al., 2006). There is still a lack of comprehensive assessment of growth and development including multiple endpoints in a full life cycle from fertilization to sexual maturation in fish exposed to E3. E3 has been detected in natural rivers in many countries at concentrations of 0.6-3.1 ng/L in seven Rivers, Paris, France (Cargouët et al., 2004), ND (not detected)-2.3 ng/L in the Atibaia River, Brazil (Sodré et al., 2010), ND-1.9 ng/L in surface waters, Austria (Hohenblum et al., 2004) and ND-10.8 ng/L in Yongding New River, China (Lei et al., 2009). At these environmental concentrations of E3, it is not known whether the growth, development and reproduction of aquatic organisms such as fish are affected by E3.

The present study investigates the impact of E3 on the embryonic development, sex differentiation, growth, and changes of functional genes related to reproduction of medaka ( 0 . latipes) exposed to different concentrations of E3 during embryo-larval-, juvenile- and adult life stages. The corresponding time to hatching, hatchability, gross abnormalities, sex ratio, hepatosomatic index (HSI), gonadosomatic index (GSI), and changes of Vtg-I and ER $\alpha$ genes in livers of the fish exposed to E3 for 90 days were determined. Our study aimed to comprehensively evaluate the estrogenic potency of E3 in Japanese medaka.

\section{Materials and methods}

\subsection{Test compounds and test fish}

Estriol was purchased from Sigma-Aldrich, USA. The purity of E3 was higher than $99 \%$. The stock solution was prepared by diluting the chemical in high-performance liquid chromatography (HPLC)-grade dimethyl sulfoxide (DMSO). All the other chemicals were analytical or HPLC grade.

Japanese ricefish (Oryzias latipes; medaka) (d-rR strain) used for the experiment were kindly provided by Y. Wakamatsu (Laboratory of Freshwater Fish at the Bioscience Center of Nagoya University, Japan). The brood stock has been maintained in the laboratory for more than 5 years. Medaka were kept in charcoal-dechlorinated tap water ( $\mathrm{pH}$ 7.2-7.6; hardness 44.0-61.0 $\mathrm{mg} \mathrm{CaCO}_{3} / \mathrm{L}$ ) at a constant temperature $\left(25 \pm 1{ }^{\circ} \mathrm{C}\right)$ with a photoperiod of $16: 8 \mathrm{~h}$ (light:dark). The brood stock was fed three times daily, once with newly hatched brine shrimp
(Artemia salina nauplii) (Binzhou Shengying aquatic Co. Ltd., Shangdong Province, China) and twice with commercial food (TetraMin, Tetra Werke, Melle, Germany) at a rate of $0.1 \%$ body weight of fish per day.

\subsection{Exposure and experimental design}

Embryos less than $4 \mathrm{~h}$ post-fertilization were used in the exposure experiments. Spawned eggs were carefully collected from the ventral side of stock females within a few hours of natural fertilizations. Egg clutches were separated by gently rolling them with a finger. Eggs were disinfected by placing them in a $0.9 \%$ solution of hydrogen peroxide for $10 \mathrm{~min}$, and then checked for fertilization using a dissecting microscope (Sun et al., 2007). The embryos were exposed to nominal E3 concentrations of 5, 50, 500 and $5000 \mathrm{ng} / \mathrm{L}$ in charcoal-dechlorinated tap water for 15 days. Each exposure level has 3 replicate test concentrations with 30 embryos per replicate. In addition, solvent controls (SC) were included in the experimental design. The SC and all E3 exposure groups contained $0.1 \mathrm{ml} / \mathrm{L}$ DMSO and $1 \%$ methylene blue. The embryos in each group were placed in a glass dish containing $100 \mathrm{~mL}$ of each test solution and incubated on a 16:8 h light: dark photoperiod cycle at $25 \pm 1{ }^{\circ} \mathrm{C}$. Eighty percent of the test solution was renewed every $24 \mathrm{~h}$. Embryos were observed twice daily at which time dead ones (identified by the incorporation of methylene blue) were removed. Hatchability, time to hatching and gross abnormalities (identified by macroscopic observation) were recorded. Once hatched, the hatched fry were continuously maintained at the same concentrations for the additional 15 days. The fish were observed daily. All dead fish were removed and recorded. After the additional 15 days of exposure, the genetic sex ratio was determined by the color of the fish. The medaka (Oryzias latipes) has an XY-XX genetic sex determination system and only the Y-chromosome carries an allele for the formation of orangered chromatophores (Scholz and Gutzeit, 2000). Therefore, males are orange-red and females are white (Edmunds et al., 2000). For Japanese medaka, the male or female fish in about 15 days post-hatch can be distinguished by color (Sun et al., 2007).

After differentiating gender of the fish, ten fish including five females and five males were assigned randomly to a 5-L glass aquarium and duplicate aquaria were used at each exposure level. Fish were continuously exposed to nominal E3 concentrations of 5, 50, 500, and $5000 \mathrm{ng} / \mathrm{L}$ and the SC was included in the experiment design. The SC aquaria and all E3 exposure aquaria received $0.1 \mathrm{ml} / \mathrm{L}$ DMSO. The solution was renewed once every $24 \mathrm{~h}$. Treated and control fish were continually exposed for another 60 days.

The entire test duration was 90 days. The medaka fish were fed three times daily. Feeding consisted of newly hatched brine shrimp (Artemia salina) for days 0-7, and a commercial food and a diet supplement of dry brine shrimp from day $7+$.

\subsection{Analytical chemistry}

The actual concentrations of test solutions were measured after exposure 0, 6 and $24 \mathrm{~h}$. The method of pretreatment and instrument analysis for water samples was based on previous report (Lei et al., 2009). Filtered water samples (2 L) of E3 were acidified and concentrated on the solid-phase extraction cartridges of Oasis HLB (HydrophilicLipophilic Balanced Copolymer). The cartridge was then rinsed sequentially with $5 \mathrm{~mL}$ of Milli-Q water and $5 \mathrm{~mL}$ of methanol/ ammonia/ultra-pure water (10:2:88, v/v/v). After drying by vacuum pressure, the analytes were eluted with $10 \mathrm{~mL}$ of methanol/tert-butyl methyl ether $(1 / 9, \mathrm{v} / \mathrm{v})$. The eluate was evaporated to just dryness and the residues of water samples were redissolved in $0.4 \mathrm{~mL}$ of hexane that contained $50 \mu \mathrm{L}$ of the derivatization mixtures of N,O-bis(trimethylsily)-trifluoroacetamide containing $1 \%$ of chlorotrimethylsilane and N-trimethylsilylimidazole (BSTFA/TCMS/ TMSI, 99:1:0.5, v/v/v) and $50 \mathrm{ng} / \mathrm{mL}$ of internal standard pyrene- $\mathrm{d}_{10}$. The derivatization was performed at $60{ }^{\circ} \mathrm{C}$ for $30 \mathrm{~min}$. Recovery of E3 
Table 1

Measured and mean ( \pm standard deviation [SD]) concentrations of estriol (E3) in the test solutions.

\begin{tabular}{|c|c|c|c|c|}
\hline \multirow[t]{3}{*}{ Nominal concn. } & \multicolumn{4}{|c|}{ Measured concn. (\% nominal) } \\
\hline & \multicolumn{3}{|c|}{ Hours after exposure } & \multirow[t]{2}{*}{ Mean \pm SD } \\
\hline & $0 \mathrm{~h}$ & $6 \mathrm{~h}$ & $24 \mathrm{~h}$ & \\
\hline Solvent control & 0 & 0 & 0 & $0 \pm 0$ \\
\hline $5 \mathrm{ng} / \mathrm{L}$ & $4.4(88.0 \%)$ & $5.3(106.0 \%)$ & $3.2(64.0 \%)$ & $4.3 \pm 1.0(86.0 \pm 21.1 \%)$ \\
\hline $50 \mathrm{ng} / \mathrm{L}$ & $54.3(108.6 \%)$ & 46.7 (93.4\%) & $38.5(77.0 \%)$ & $46.5 \pm 7.9(93.0 \pm 15.8 \%)$ \\
\hline $500 \mathrm{ng} / \mathrm{L}$ & $481.6(96.3 \%)$ & $494.1(98.8 \%)$ & $410.8(82.2 \%)$ & $462.2 \pm 44.9(92.4 \pm 9.0 \%)$ \\
\hline $5000 \mathrm{ng} / \mathrm{L}$ & 4500.7 (90.0\%) & $5030.8(100.6 \%)$ & $4018.4(80.4 \%)$ & $4516.6 \pm 506.4(90.3 \pm 10.1)$ \\
\hline
\end{tabular}

for different concentrations of spiked water samples ranged from 79 to $110 \%$. The limit of quantification (LOQ) was $0.3 \mathrm{ng} / \mathrm{L}$. The derivatized samples were analyzed by gas chromatography 6890/mass spectrometry 5975 B ([GC-MS], Agilent, Santa Clara, CA, USA).

\subsection{Specimen preparation}

At the end of the exposure, all males and females were frozen by keeping them on ice for 1-2 min and the body weight was measured. Then fish were dissected by stainless steel scissors and the livers and gonads were isolated and weight. The gonadosomatic index (GSI) and hepatosomatic index (HSI) were calculated by: GSI (HSI) = gonad (liver) weight/body weight $\times 100 \%$ (Zhang and Hu, 2008). Livers were frozen immediately in liquid nitrogen and stored at $-80{ }^{\circ} \mathrm{C}$ until the RNA was isolated.

\subsection{RNA isolation and real-time PCR}

Total RNA was isolated from frozen samples using Trizol reagent (Gibco BRL, Life Technologies, USA). RNA samples were treated with DNase I (Ambion, Huntingdon, UK) to remove contaminating genomic DNA and purified by spin column (RNeasy; Qiagen, Valencia, CA, USA) according to the manufacturer's instructions. The RNA concentrations were determined by ultraviolet-visible spectrophotometer (Model GBC, UV/VIS 918, GBC Scientific Instruments, Dandenong, VIC, Australia). The 260-nm reading was used to estimate the concentrations of total RNA. The 260/280 ratio was used to verify the quality of the RNA in each sample (Zhang et al., 2008b). Then the RNA samples were dissolved in ribonuclease-free water and stored at $-80{ }^{\circ} \mathrm{C}$ until the process of reverse-transcriptase polymerase chain reaction.

The processes of reverse-transcriptase polymerase chain reaction and real-time PCR were performed according to the methods described previously (Li et al., 2009; Lei et al., 2013b). The reverse transcription reaction mixtures contain $10 \mu \mathrm{L}(100 \mathrm{ng} / \mu \mathrm{L})$ of total RNA and $2 \mu \mathrm{L}$ of random primers. The primers of ER $\alpha$ and VTG-I genes were reported by Zhang and Hu (2008). All the samples were analyzed in triplicate and the mean value of these triplicate measurements was used for calculations of mRNA expressions. The housekeeping gene $\beta$-action was used as the internal control and gene expression data are presented as fold changed relative to control fish within the same treatment period (Zhang et al., 2008a).

\subsection{Statistical analysis}

All statistical analyses were completed by using SPSS 13.0 (SPSS, Chicago, IL, USA) and Origin 8.0 (OriginLab, Northampton, MA, USA). The data were subjected to one-way analysis of variance (ANOVA) with specific means comparisons by Dunnett's test. Prior to data analysis, the experimental data were checked for assumptions of normality using Kolmogorov-Smirnov one-sample test and Shapiro-Wilk test. In order to avoid biases associated with size-specific indices, analysis of covariance (ANCOVA) with body weight of medaka as a covariate was used to compare the GSI and HSI among all experimental groups. The critical values for statistical significance were $p \leq 0.05$ or $p \leq 0.01$.

\section{Results}

\subsection{Measured concentrations of E3}

Water samples were collected at exposure times of $0 \mathrm{~h}, 6 \mathrm{~h}$ and $24 \mathrm{~h}$ from 5-L glass aquarium and the mean concentrations of $\mathrm{E} 3$ in the test solutions were measured (Table 1). E3 was not detected in the solvent control (SC). The mean measured concentrations of E3 for three time points were between $64.0 \%$ and $108.6 \%$ of the nominal concentrations. Nominal E3 were used in the following text. In addition, at $24 \mathrm{~h}$, the measured concentration ranges of E3 were $64.0-80.4 \%$ of the nominal concentrations which indicated that E3 may be partially degraded. To ensure a relatively stable exposure concentration of E3 during the experiment period, the solution was renewed every $24 \mathrm{~h}$.

\subsection{Effects on the embryonic development of medaka}

Less than 4 h post-fertilization embryos were continuously exposed to E3 for 15 days through the major embryonic stages (blastula, gastrula, neurula and organogenesis), hatching and into the larval stage. Exposure to higher concentrations of E3 had adverse effects on the hatchability and time to hatching of spawned embryos (Table 2). At 500 and $5000 \mathrm{ng} / \mathrm{L} \mathrm{E3}$, the hatchability of fertilized eggs was significantly decreased and time to hatching was significantly delayed relative to the controls $(p<0.05)$. Exposure to the highest concentration of E3 led to a significant increase in the gross abnormality rate relative to the controls $(p=0.029)$. The two most common abnormal features in hatched fry were scoliosis and abdominal swelling.

Table 2

Hatchability, time to hatching, gross abnormalities rate of fertilized eggs (mean \pm SD) exposed to E3 for 15 days and sex ratio of the fish after the additional 15 days of exposure.

\begin{tabular}{|c|c|c|c|c|}
\hline E3 (ng/L) & Hatchability (\%) & Time to hatching (days) & Gross abnormality rate (\%) & Sex ratio (Female:Male) \\
\hline SC & $94.4 \pm 3.8\left(85^{\mathrm{a}}\right)$ & $11.7 \pm 0.6$ & $3.6 \pm 3.7\left(3^{\mathrm{b}}\right)$ & $1.1: 1(42: 38)$ \\
\hline 5 & $95.6 \pm 1.9\left(86^{\mathrm{a}}\right)$ & $12.0 \pm 1.0$ & $2.3 \pm 2.0\left(2^{b}\right)$ & $1.1: 1(44: 39)$ \\
\hline 50 & $93.3 \pm 3.3\left(84^{a}\right)$ & $12.7 \pm 1.2$ & $4.8 \pm 5.7\left(4^{\mathrm{b}}\right)$ & $1.3: 1(40: 31)$ \\
\hline 500 & $87.8 \pm 3.8^{*}\left(79^{a}\right) p=0.048$ & $13.3 \pm 0.6^{*} p=0.012$ & $7.5 \pm 6.3\left(6^{\mathrm{b}}\right)$ & $1.5: 1(38: 25)$ \\
\hline 5000 & $78.9 \pm 10.7^{*}\left(71^{\mathrm{a}}\right) p=0.039$ & $13.7 \pm 1.2^{*} p=0.027$ & $14.5 \pm 6.0^{*}\left(10^{\mathrm{b}}\right) p=0.029$ & $2.1: 1(36: 17)$ \\
\hline
\end{tabular}

The asterisk $\left({ }^{*}\right)$ denotes statistically significant difference compared with the solvent control $(p<0.05)$.

a Denotes the total numbers of hatched fish at different exposure levels.

b Denotes the total numbers of abnormal fish at different exposure levels. 

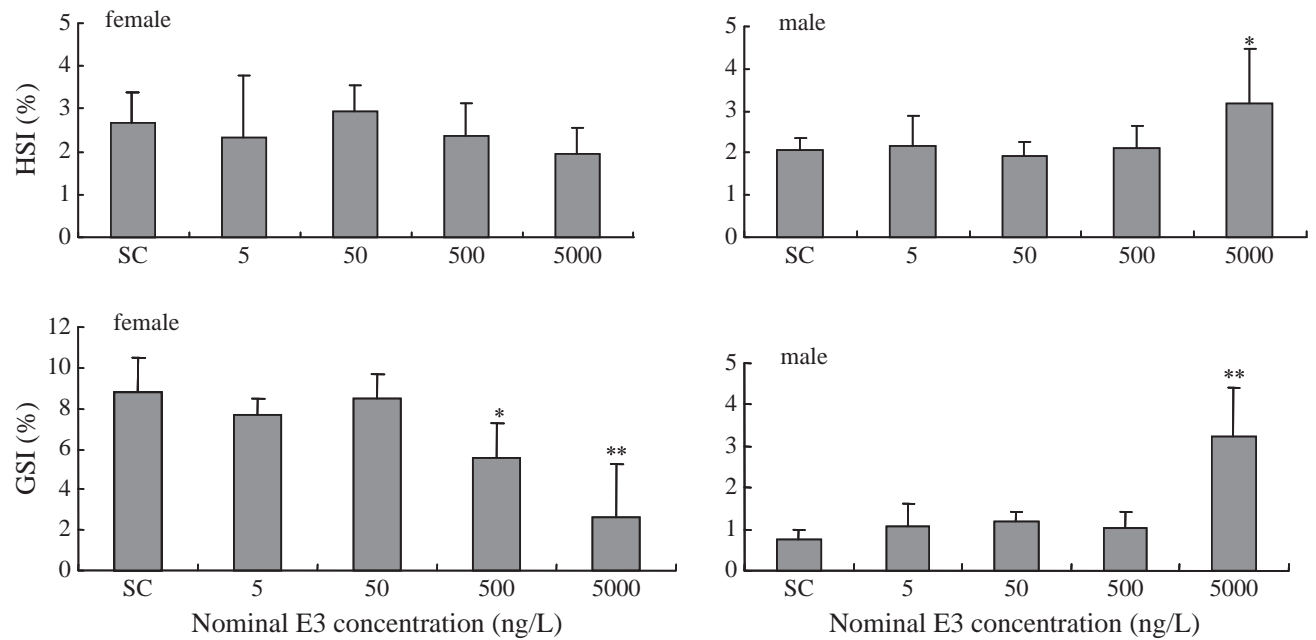

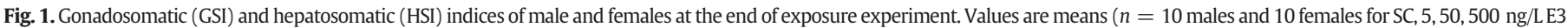

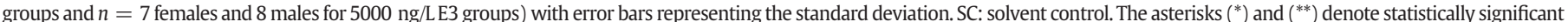
difference compared with the solvent control $(p<0.05 ; p<0.01)$, respectively.

After the additional 15 days of exposure, males and females were counted simply by the color of the fish. The female:male ratio at $50 \mathrm{ng} / \mathrm{L} \mathrm{E} 3$ and above was higher than that in the control groups, and there were twice as many females as males at $5000 \mathrm{ng} / \mathrm{L} \mathrm{E3}$ (Table 2).

\subsection{Tissue somatic indices}

The HSI and GSI in males and females exposed to E3 for 90 days are shown in Fig. 1. Covariance analysis revealed that there was no significant difference in the female HSI between the controls and E3 groups, while a significant increase in the male HSI was found at $5000 \mathrm{ng} / \mathrm{L} \mathrm{E3}$ $(p<0.01)$. Compared to SC, E3 led to a marked decrease in female GSI at 500 and $5000 \mathrm{ng} / \mathrm{L}(p=0.028$ at $500 \mathrm{ng} / \mathrm{L}$, and $p<0.01$ at $5000 \mathrm{ng} / \mathrm{L}$ ), while a significant increase in male GSI was only found at $5000 \mathrm{ng} / \mathrm{L} \mathrm{E3}(p<0.01)$.

Sex reversal in male fish was identified by autopsy. Males with red color on the tail, a mature ovary and absence of testes were identified as sex reversal fish. Four males at $5000 \mathrm{ng} / \mathrm{L} \mathrm{E3}$ were found to show sex reversal at the end of the exposure experiment (Table 3 ). In addition, the ovaries of two females at $500 \mathrm{ng} / \mathrm{L}$ and six females at $5000 \mathrm{ng} / \mathrm{L}$ were shown to be degenerative by macroscopic observation. Mortality was also only found in the 5000 ng/L E3 groups. At 5000 ng/L E3, three females and two males died (Table 3). In these dead fish, three females and one male were abnormal (data not shown in Table 3). In the surviving fish, four fish including three females and one male were abnormal. One of the most common abnormalities was abdominal swelling (identified by macroscopic observation).

\subsection{Quantification of ER and Vtg by real-time PCR}

The ER $\alpha$ and Vtg-I gene mRNA levels in medaka fish exposed to the solvent control (SC) and E3 are presented in Fig. 2. In both male and female fish, there was no statistical difference between E3 treatments and controls in ER $\alpha$ gene expression; however, in male fish, Vtg-I gene mRNA levels showed significant up-regulation at all E3 treatment groups ( $p<0.05)$. In the females, significant up-regulation of Vtg-I gene expression was only found at 500 and $5000 \mathrm{ng} / \mathrm{L} \mathrm{E3}$ ( $p=0.027$ at $500 \mathrm{ng} / \mathrm{L}$ and $p<0.01$ at $5000 \mathrm{ng} / \mathrm{L}$ ).

\section{Discussion}

At E3 concentrations of 500 and $5000 \mathrm{ng} / \mathrm{L}$, adverse effects on hatchability and time to hatching were observed, and a significantly high abnormality rate in hatched fry was found at $5000 \mathrm{ng} / \mathrm{L} \mathrm{E3}$. E3 has a lipophilicity $\log k_{\text {ow }}$ estimated to be 2.8 (Lai et al., 2000) which can partition into lipid compartments (e.g. membranes). Therefore, it would be expected that $\mathrm{E} 3$ can cross egg barrier and get into the developing embryo from water and interfere with normally embryonic development process. Other (xeno)-estrogens like NP, E2 and bisphenol A (BPA) affecting the embryonic development and hatching process in transgenic medaka embryos have been reported by Lee et al. (2012). The sex ratio of female:male at $50 \mathrm{ng} / \mathrm{L} \mathrm{E3}$ or above was higher than that in the SC group (Table 2). Estrogens are active at sex steroid receptors and possess the potential to alter normal sexual differentiation in fish to produce more females. Numerous studies have reported that fish such as medaka (0. latipes), Chinese rare minnow (Gobiocypris rarus), zebra fish (Danio rerio) and guppies (Poecilia reticulata) exposed to estrogens like E2 or EE2 can cause female-biased phenotypic sexratios (Scholz and Gutzeit, 2000; Toft and Baatrup, 2003; Fenske et al., 2005; Zha et al., 2008). In our previous studies, we found that exposure to EV and E1 led to more female medaka fish in genotypic sex-ratios (Lei et al., 2013a;b). However, in these two studies, statistical significant analysis for sex ratio between treatments and controls was not performed. To our knowledge, only one paper has reported the significant

Table 3

Effect of E3 on survival, abnormality and sex reversal of medaka for further 60 days of exposure.

\begin{tabular}{|c|c|c|c|c|}
\hline E3 (ng/L) & Exposed females/males & Surviving females/males & Abnormality females/males & Sex reversed males \\
\hline SC & $10 / 10$ & $10 / 10$ & $0 / 0$ & 0 \\
\hline 5 & $10 / 10$ & $10 / 10$ & $0 / 0$ & 0 \\
\hline 50 & $10 / 10$ & $10 / 10$ & $0 / 0$ & 0 \\
\hline 500 & $10 / 10$ & $10 / 10$ & $2 / 0$ & 0 \\
\hline 5000 & $10 / 10$ & $7 / 8$ & $6^{\mathrm{a}} / 2^{\mathrm{b}}$ & 4 \\
\hline
\end{tabular}

SC: solvent control.

a Denotes the abnormal females that included three dead females and three surviving females during the 60 days of exposure.

benotes the abnormal males that included one dead male and one surviving male during the 60 days of exposure. 

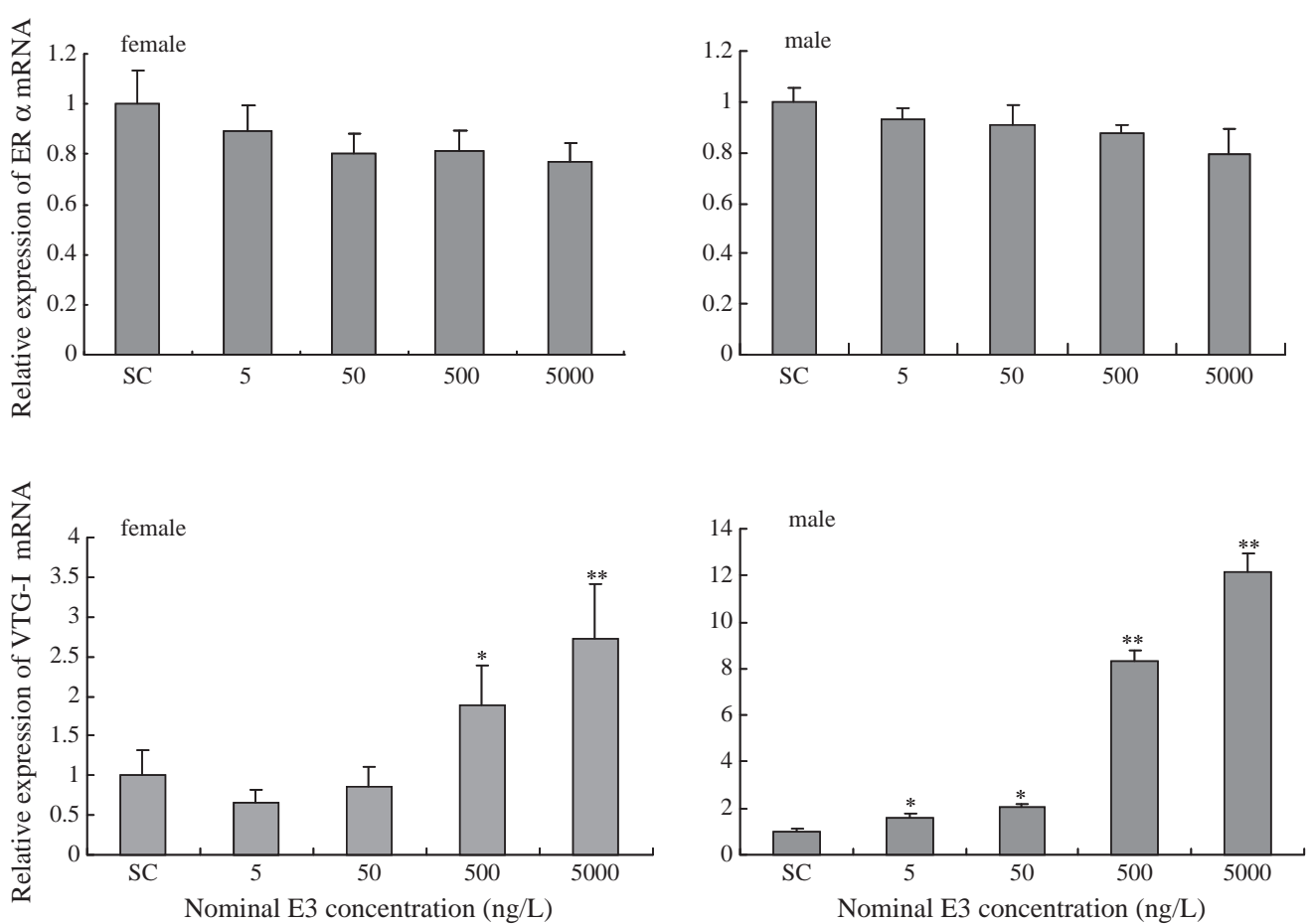

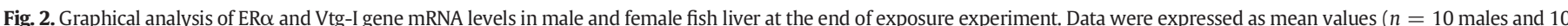

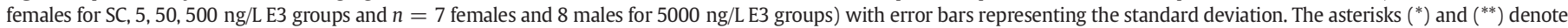
statistically significant difference compared with the solvent control $(p<0.05 ; p<0.01)$, respectively.

alteration of genotypic sex ratio in fish exposed to tamoxifen. Sun et al. (2007) found a significant increase in the proportion of F1 male 0 . latipes relative to the controls when breeding pairs medaka were exposed to anti-estrogen tamoxifen for 21 days. They think that the observed change in sex ratio may be caused by differential sensitivity of spermatozoa (i.e. the spermatozoa with the $\mathrm{X}$ chromosome may be more sensitive to tamoxifen than one carrying the $Y$ chromosome) resulting in more spermatozoa with Y chromosome. Similarly, if the embryo and fry of medaka with the XY chromosome were more sensitive to $\mathrm{E} 3$ than the embryo and fry carrying the XX chromosome leading to more dead embryos or fry with the XY chromosome, the higher proportion of female Japanese medaka could be obtained. However, the specific reasons for the change in sex ratio in the fish exposed to E3 require further study.

At a concentration of $5000 \mathrm{ng} / \mathrm{L}$, E3 led to sex reversal of four males, which indicated that high concentrations of E3 can induce feminization of fish. Sex reversal in fish exposed to EDCs has been reported previously and may involve estrogenic chemicals eliciting female characteristics in males or androgenic chemicals producing male traits in females (Iwamatsu et al., 2000; Sun et al., 2007). Sex reversal of male fish is considered a consequence of the transformation from testes to ovaries during early gonadal development under the direct influence of environmental estrogens (Zha et al., 2008). Some studies have reported that EV is used in aquaculture for sex reversal to produce more female fish in a population (Senol et al., 2008; Chu et al., 2011). Even if a weakly estrogenic pesticide such as o, p'-DDT is present during the critical period of gonadal development of $O$. latipes, it can also profoundly alter sex (Edmunds et al., 2000). Lange et al. (2012) reported that E3 may play an important role in the feminization process in roach. Holbech et al. (2006) investigated water exposure of juvenile zebrafish to E3 for 40 days and found that the sex ratio was significantly altered towards females from $22 \mu \mathrm{g} / \mathrm{L}$ E3. At $10 \mu \mathrm{g} / \mathrm{LE} 3$, the well-defined testis-ova identified from histological examination of the gonad was presented in all 35 male medaka fish, whereas only one male medaka fish with testis-ova among 40 examined males was observed at $1 \mu \mathrm{g} / \mathrm{L}$ E3 (Metcalfe et al., 2001). These results indicated that E3 only at higher exposure concentrations can induce feminization of male fish. This is consistent with our results where sex reversal of males was only observed at the highest concentration of E3 (5000 ng/L). The capacity of E3 to induce feminization of medaka fish was weaker than that of E2, EE2 and EV. These three estrogens at environmental concentrations of $1-10 \mathrm{ng} / \mathrm{L}$ and a similar exposure period can result in sex reversal or feminization of male medaka (Caldwell et al., 2012; Lei et al., 2013a). However, this may have some limitations about sensitivities with respect to extrapolating to other medaka populations, because the same brood stock medaka fish in this study have been used for over 5 years.

Endpoints such as GSI and HSI are general measures of the growth status of specific tissues in fish (Scholz and Gutzeit, 2000; Zhang et al., 2008a). The GSI in males at all E3 treatments was higher than that in the SC groups. However, a statistically significant increase was only observed at $5000 \mathrm{ng} / \mathrm{L} \mathrm{E3}$. In addition, sex reversal of males was also found at $5000 \mathrm{ng} / \mathrm{LE}$. The higher male GSI may be due to sex reversal of male fish. The sex of medaka can be functionally reversed if estrogens are applied during a sensitive period of embryonic or juvenile development (Iwamatsu et al., 2000). In these sex reversal male fish with the redcolored tails, their testes were replaced by mature ovaries. The GSI in females was significantly decreased at 500 and $5000 \mathrm{ng} / \mathrm{L} \mathrm{E3}$. The low GSI in female O. latipes may be due to ovary degeneration (Scholz and Gutzeit, 2000). Seki et al. (2002) reported regression of ovaries in adult female medaka (Oryzias latipes) exposed to $488 \mathrm{ng} / \mathrm{L} \mathrm{EE} 2$ for three weeks using tissue histopathology. Decreased GSI was also observed in female rare minnows (G. rarus) when exposed to EE2 (Zha et al., 2008) and 4-NP (Zhang et al., 2008b). The HSI in males and females was not significantly different between the E3 treatment groups and SC groups, except that the male HSI at $5000 \mathrm{ng} / \mathrm{L} \mathrm{E3}$ was significantly increased. These results showed that E3 at environmental concentration of $5 \mathrm{ng} / \mathrm{L}$ has no adverse effects on the growth status of specific tissues in fish.

Vtg-I gene mRNA levels in the male fish showed dose-dependent in all E3 treatments. Zhang and $\mathrm{Hu}$ (2008) also found good dose-response relationship in changes in Vtg-I gene expression in the liver of male juvenile 0 . latipes exposed to anti-androgenic p,p'-DDE for 60 days. 
The dose-dependent relationship is one of many concentrationdependent patterns in gene expression changes. Osachoff et al. (2013) examined changes in liver gene expression in juvenile Chinook salmon (Oncorhynchus tshawytscha) exposed to 5 concentrations of sewage for 1-8 days and found four distinct concentration-dependent patterns: concentration response, inverse-concentrations response, U-shaped and inverse U-shaped. And the patterns in gene expression changes were found across sewage concentrations and exposure timepoints (Osachoff et al., 2013). The Vtg gene in male fish is generally accepted as a suitable biomarker for estrogenic effects and this was confirmed for E3 in this study. The fact that all concentrations of E3 significantly up-regulated male Vtg gene levels (Fig. 2) indicated that the threshold of E3 for Vtg gene expression change was actually lower than $5 \mathrm{ng} / \mathrm{L}$. While E3 at $5 \mathrm{ng} / \mathrm{L}$ had no significant adverse effects on hatchability, time to hatching, gross morphology, growth and ER gene expression, Vtg gene expression in males is considered be a more sensitive indicator. Generally, Vtg production in the liver is under the control of the ER pathway in fish (Ishibashi et al., 2008). Numerous experimental studies have reported that liver Vtg and ER mRNA levels increased simultaneously after the treatment of fish with (xeno)-estrogens (Atteke et al., 2003; Andreassen et al., 2005; Zhang and Hu, 2008; Adedeji et al., 2012). Flouriot et al. (1997) considered that the upregulation of Vtg mRNA depends directly on the number of estrogen receptors (ER), which are also regulated at the mRNA level by estrogen treatment in fish. However, in this study, we noted significant increases in the hepatic Vtg gene levels and no decrease statistically in ER $\alpha$ gene levels in fish treated with E3. The results of this study are similar to those of our another study which reported that the up-regulation of hepatic Vtg mRNA was observed in male fish after exposure to EV, however there was no statistical decrease in the hepatic ER $\alpha$ mRNA levels (Lei et al., 2013a). Arukwe et al. (2001) also reported that the hepatic Vtg gene levels in juvenile rainbow trout (Oncorhychus mykiss) exposed to E2 and NP for 2-72 h did not change significantly at $24 \mathrm{~h}$ and was significantly up-regulated at 48 and $72 \mathrm{~h}$, while induction of ER gene transcripts was observed at $24 \mathrm{~h}$ and did not change significantly at 48 and 72 h. In addition, Arukwe et al. (2001) found that Vtg transcripts showed an apparent time-dependent increase without a concomitant increase in protein levels in the 25-mg NP treated fish. They concluded that the E2- and NP-induced Vtg gene expressions were not dependent on an increase in the transcriptional activity of the ER gene, and Vtg gene transcriptions require only basal or minimal ER concentrations. Similarly, our results also indicated that E3-induced Vtg-I gene expression in medaka fish did not relate to the transcriptional activity of the ER gene. However, in the present study, we did not investigate ER and Vtg protein levels in the fish exposed to E3, so we could not obtain the relationships between gene expression changes and functional protein level changes. Therefore, the detailed mechanisms by which E3 does not affect ER $\alpha$ mRNA transcription and up-regulates Vtg mRNA levels in fish require further study.

\section{Conclusions}

E3 has been detected in many rivers and the highest concentrations of E3 in natural rivers were $10.8 \mathrm{ng} / \mathrm{L}$. Therefore, environmental levels of E3 are considerably less than the high concentrations of 500 and $5000 \mathrm{ng} / \mathrm{L}$ associated with the hatchability, time to hatching and gross abnormality rate, HSI and GSI endpoints reported in the present study. E3 alone may not affect the early life stages and growth of fish in natural aquatic environments. However, it should be noted that E3 is one of many EDCs that may contribute additively to a common effect or may interact synergistically or antagonistically.

In addition, in light of our results, the Vtg gene in male medaka fish can be induced by E3 at environmentally relevant concentration of $5 \mathrm{ng} / \mathrm{L}$. Therefore, in this study, if Vtg gene change in males is recommended as the biomarker for assessing the estrogenic effects of E3 on fish, we can conclude that as a natural estrogen, E3 may be considered a potent estrogenic compound. However, we have to note that the Vtg mRNA changes are hardly ever reflected in concomitant changes in functional protein. Therefore, further studies are needed to detect more sex hormone pathway gene expressions and functional protein levels to evaluate comprehensively estrogen potency of E3 in fish.

\section{Acknowledgments}

This work was supported by the National Natural Science Foundation of China (NSFC51290283) and the Shanghai Leading Academic Discipline (Grant No. S30109).

\section{References}

Adedeji, O.B., Durhan, E.J., Garcia-Reyero, N., Kahl, M.D., Jensen, K.M., LaLone, C.A., Makynen, E.A., Perkins, E.J., Thomas, L., Villeneuve, D.L., Ankley, G.T., 2012. Shortterm study investigating the strogenic potency of diethylstilbesterol in the Fathead Minnow (Pimephales promelas). Environ. Sci. Technol. 46, 7826-7835.

Andreassen, T.K., Skjoedt, K., Korsgaard, B., 2005. Upregulation of estrogen receptor $\alpha$ and vitellogenin in eelpout (Zoarces viviparous) by waterborne exposure to 4-tertoctylphenol and 17beta-estrodiol. Comp. Biochem. Physiol. C: Toxicol. Pharmacol. 140, 340-346.

Arukwe, A., Kullman, S.W., Hinton, D.E., 2001. Differential biomarker gene and protein expressions in nonylphenol and estradiol-17ß treated juvenile rainbow trout (Oncorhynchus mykiss). Comp. Biochem. Physiol. C: Toxicol. Pharmacol. 129, 1-10.

Atteke, C., Vetillard, A., Fostier, A., Garnier, D.H., Jego, P., Bailhache, T., 2003. Effect of progesterone and estradiol on the reproductive axis in immature diploid and triploid rainbow trout. Comp. Biochem. Physiol. A Mol. Integr. Physiol. 134, 693-705.

Boyce-Derricott, J., Nagler, J.J., Cloud, J.G., 2009. Regulation of hepatic estrogen receptor isoform mRNA expression in rainbow trout (Oncorhynchus mykiss). Gen. Comp. Endocrinol. 161, 73-78.

Caldwell, D.J., Mastrocco, F., Anderson, P.D., Länge, R., Sumpter, J.P., 2012. Predicted-noeffect concentrations for the steroid estrogens estrone,17 $\beta$-estradiol, estriol, and $17 \alpha$-ethinylestradiol. Environ. Toxicol. Chem. 31, 1396-1406.

Cargouët, M., Perdiz, D., Mouatassim-Souali, A., Tamisier-Karolak, S., Levi, Y., 2004. Assessment of river contamination by estrogenic compounds in Paris area (France). Sci. Total Environ. 324, 55-66.

Chakraborty, T., Katsu, Y.,Zhou, L.Y., Miyagawa, S., Nagahama, Y., Iguchi, T., 2011. Estrogen receptors in medaka (Oryzias latipes) and estrogenic environmental contaminants: an in vitro-in vivo correlation. J. Steroid Biochem. 123, 115-121.

Chen, H., Hu, J.Y., Yang, J., Wang, Y.X., Xu, H., Jiang, Q., Gong, Y.B., Gu, Y.L., Song, H.Y., 2010. Generation of a fluorescent transgenic zebrafish for detection of environmental estrogens. Aquat. Toxicol. 96, 53-61.

Chu, Z.J., Wu, Y.X., Gong, S.Y., Zhang, G.B., Zhang, L., Yuan, Y.C., Yuan, H.W., 2011. Effects of estradiol valerate on steroid hormones and sex reversal of female rice field eel, Monopterus albus (Zuiew). J. World Aquacult. Soc. 42, 96-104.

Denny, J.S., Tapper, M.A., Scmieder, P.K., Hornung, M.W., Jensen, K.M., Ankley, G.T., Henry, T.R., 2005. Comparison of relative binding affinities of endocrine active compounds to fathead minnow and rainbow trout estrogen receptors. Environ. Toxicol. Chem. 24, $2948-2953$

Edmunds, J.S., McCarthy, R.A., Ramsdell, J.S., 2000. Permanent and functional male to female sex reversal in d-rR strain medaka (Oryzias latipes) following egg microinjection of o, p'-DDT. Environ. Health Perspect. 108, 219-224.

Fenske, M., Maack, G., Schaefers, C., Segner, H., 2005. An environmentally relevant concentration of estrogen induces arrest of male gonad development in zebrafish (Danio rerio). Environ. Toxicol. Chem. 24, 1088-1098.

Flouriot, G., Pakdel, F., Ducouret, B., Ledrean, Y., Valotaire, Y., 1997. Differential regulation of two genes implicated in fish reproduction: vitellogenin and estrogen receptor genes. Mol. Reprod. Dev. 48, 317-323.

Hawkins, M.B., Thornton, J.W., Crews, D., Skipper, J.K., Dotte, A., Thomas, P., 2000. Identification of a third distinct estrogen receptor and reclassification of estrogen receptors in teleosts. Proc. Natl. Acad. Sci. U. S. A. 97, 10751-10756.

Hohenblum, P., Gans, O., Moche, W., Scharf, S., Lorbeer, G., 2004. Monitoring of selected estrogenic hormones and industrial chemicals in groundwaters and surface waters in Austria. Sci. Total Environ. 333, 185-193.

Holbech, H., Kinnberg, K., Petersen, G.I., Jackson, P., Hylland, K., Norrgren, L., Bjerregaard, P., 2006. Detection of endocrine disrupters: evaluation of a Fish Sexual Development Test (FSDT). Comp. Biochem. Physiol. C: Pharmacol. Toxicol. 144, 57-66.

Huang, C., Zhang, Z.B., Wu, S.M., Zhao, Y.B., Hu, J.Y., 2010. In vitro and in vivo estrogenic effects of $17 \alpha$-estradiol in medaka (Oryzias latipes). Chemosphere 80, 608-612.

Ishibashi, H., Yamauchi, R., Matsuoka, M., Kim, J.W., Hirano, M., Yamaguchi, A., Tominaga, N., Arizono, K., 2008. Fluorotelomer alcohols induce hepatic vitellogenin through activation of the estrogen receptor in male medaka (Oryzias latipes). Chemosphere $71,1853-1859$

Iwamatsu, T., Kobayashi, H., Hamaguchi, S., Sagegami, R., Shuo, T., 2000. Sex reversal of medaka (Oryzias latipes) by a short exposure of embryos to sex steroids. Zool. Sci. $17,15-28$.

Jobling, S., Williams, R., Johnson, A., 2006. Predicted exposures to steroid estrogens in UK rivers correlate with widespread sexual disruption in wild fish populations. Environ. Health Perspect. 114, 32-39. 
Lai, K.M., Johnson, K.L., Scrimshaw, M.D., Lester, J.N., 2000. Binding of waterborne steroid estrogens to solid phases in river and estuarine systems. Environ. Sci. Technol. 34 3890-3894.

Lange, A., Paull, G.C., Hamilton, P.B., Iguchi, T., Tyler, C.R., 2011. Implications of persistent exposure to treated wastewater effluent for breeding in wild roach (Rutilus rutilus) populations. Environ. Sci. Technol. 45, 1673-1679.

Lange, A., Katsu, Y., Miyagawa, S., Ogino, Y., Urushitani, H., Kobayashi, T., Hirai, T., Shears, J.A., Nagae, M., Yamamoto, J., Ohnishi, Y., Oka, T., Tatarazako, N., Ohta, Y., Tyler, C.R., Iguchi, T., 2012. Comparative responsiveness to natural and synthetic estrogens of fish species commonly used in the laboratory and field monitoring. Aquat. Toxicol. 109, 250-258.

Lappano, R., Rosano, C., De Marco, P., De Francesco, E.M., Pezzi, V., Maggiolini, M., 2010. Estriol acts as a GPR30 antagonist in estrogen receptor-negative breast cancer cells. Mol. Cell. Endocrinol. 32, 162-170.

Lee, W., Kang, C.W., Su, C.K., Okubo, K., Nagahama, Y., 2012. Screening estrogenic activity of environmental contaminants and water samples using a transgenic medaka embryo bioassay. Chemosphere 88, 945-952.

Lei, B.L., Huang, S.B., Zhou, Y.Q., Wang, D.H., Wang, Z.J., 2009. Levels of six estrogens in water and sediment from three rivers in Tianjin area, China. Chemosphere 76, 36-42.

Lei, B.L., Kang, J., Yu, Y.X., Zha, J.M., Li, W., Wang, Z.J., 2013a. B-estradiol 17-valerate affects embryonic development and sexual differentiation in Japanese medaka (Oryzias latipes). Aquat. Toxicol. 134-135, 128-134.

Lei, B.L., Wen, Y., Wang, X.T., Zha, J.M., Li, W., Wang, Z.J., Sun, Y.F., Kang, J., Wang, Y.P. 2013b. Effects of estrone on the early life stage and expression of vitellogenin and estrogen receptor genes of Japanese medaka (Oryzias latipes). Chemosphere 93, 1104-1110.

Li, W., Zha, J.M., Li, Z.L., Yang, L.H., Wang, Z.J., 2009. Effects of exposure to acetochlor on the expression of thyroid hormone related genes in larval and adult rare minnow (Gobiocypris rarus). Aquat. Toxicol. 94, 87-93.

Luo, J.P., Lei, B.L., Ma, M., Zha, J.M., Wang, Z.J., 2011. Identification of estrogen receptor agonists in sediments from Wenyu River, Beijing, China. Water Res. 45, 3908-3914.

Metcalfe, C.D., Metcalfe, T.L., Kiparissis, Y., Koenig, B.G., Khan, C., Hughes, R.J., Croley, T.R., March, R.E., potter, T., 2001. Estrogenic potency of chemicals detected in sewage treatment plant effluents as determined by in vivo assays with Japanese medaka (Oryzias latipes). Environ. Toxicol. Chem. 20, 297-308.

Nash, J.P., Kime, D.E., Van den Ven, L.T.M., Wester, P.W., Brion, F., Maack, G., StahlschmidtAllner, P., Tyler, C.R., 2004. Long-term exposure to environmental concentrations of the pharmaceutical ethynylestradiol causes reproductive failure in fish. Environ. Health Perspect. 112, 1725-1733.

Osachoff, H.L., van Aggelen, G.C., Mommsen, T.P., Kennedy, C.J., 2013. Concentrationresponse relationships and temporal patterns in hepatic gene expression of Chinook salmon (Oncorhynchus tshawytscha) exposed to sewage. Comp. Biochem. Physiol. D: Genomics Proteomics 8, 32-44.

Saaristo, M., Craft, J.A., Lehtonen, K.K., Björk, H., Lindström, K., 2009. Disruption of sexual selection in sand gobies (Pomatoschistus minustus) by $17 \alpha$-ethinylestradiol, and endocrine disruptor. Horm. Behav. 55, 530-537.
Saaristo, M., Craft, J.A., Lehtonen, K.K., Lindström, K., 2010. Exposure to $17 \alpha$-ethinyl estradiol impairs courtship and aggressive behaviour of male sand gobies (Pomatoschistus minutus). Chemosphere 79, 541-546.

Scholz, S., Gutzeit, H.O., 2000. 17-alpha-ethinylestradiol affects reproduction, sexual differentiation and aromatase gene expression of the medaka (Oryzias latipes). Aquat. Toxicol. 50, 363-373.

Seki, M., Yokota, H., Matsubara, H., Tsuruda, Y., Maeda, M., Tadokoro, H., Kobayashi, K., 2002. Effect of ethinylestradiol on the reproduction and induction of vitellogenin and testis-ova in medaka (Oryzias latipes). Environ. Toxicol. Chem. 21, 1692-1698.

Sellin, M.K., Snow, D.D., Kolok, A.S., 2010. Reductions in hepatic vitellogenin and estrogen receptor alpha expression by sediments from an agriculturally impacted waterway. Aquat. Toxicol. 96, 103-108.

Senol, G., Mecit, Y., Kenan, G., Turan, K., 2008. Effects of oral administration of estradio valerate on gonadal sex differentiation in the rainbow trout, Oncorhynchus mykiss. J. Anim. Vet. Adv, 7, 1400-1404.

Sodré, F.F., Pescara, I.C., Montagner, C.C., Jardim, W.F., 2010. Assessing selected estrogens and xenoestrogens in Brazilian surface waters by liquid chromatography-tandem mass spectrometry. Microchem. J. 96, 92-98.

Sun, L.W., Zha, J.M., Spear, P.A., Wang, Z.J., 2007. Tamoxifen effects on the early life stages and reproduction of Japanese medaka (Oryzias latipes). Environ. Toxicol. Pharm. 24, 23-29.

Toft, G., Baatrup, E., 2003. Altered sexual characteristics in guppies (Poecilia reticulate) exposed to $17 \beta$-estradiol and 4-tert-octylphenol during sexual development. Ecotoxicol. Environ. Saf. 56, 228-237.

Tollefsen, K.E., Mathisen, R., Stenersen, J., 2003. Induction of vitellogenin synthesis in an Atlantic salmon (Salmo salar) hepatocyte culture: a sensitive in vitro bioassay for the oestrogenic and anti-oestrogenic activity of chemicals. Biomarkers 8, 394-407.

Van Aerle, R., Nolan, M., Jobling, S., Christiansen, L.B., Sumpter, J.P., Tyler, C.R., 2001. Sexual disruption in a second species of wild cyprinid fish (the gudgen, Gobio gobio) in United Kingdom freshwaters. Environ. Toxicol. Chem. 20, 2841-2847.

Yan, Z.H., Lu, G.H., Liu, J.C., Jin, S.G., 2012. An integrated assessment of estrogenic contamination and feminization risk in fish in Taihu Lake, China. Ecotoxicol. Environ. Saf. 84, 334-340.

Zha, J., Sun, L., Zhou, Y., Spear, P., Ma, M., Wang, Z., 2008. Assessment of 17aethinylestradiol effects and underlying mechanisms in a continuous, multigeneration exposure of the Chinese rare minnow (Gobiocypris rarus). Toxicol. Appl. Pharm. 226, 298-308.

Zhang, Z.B., Hu, J.Y., 2008. Effects of p, p'-DDE exposure on gonadal development and gene expression in Japanese medaka (Oryzias latipes). J. Environ. Sci. 20, 347-352.

Zhang, X.Y., Zha, J.M., Li, W., Yang, L.H., Wang, Z.J., 2008a. Effects of 2,4-dichlorophenol on the expression of vitellogenin and estrogen receptor genes and physiology impairments in Chinese rare minnow (Gobiocypris rarus). Environ. Toxicol. 23 694-701.

Zhang, X.Y., Zha, J.M., Wang, Z.J., 2008b. Influences of 4-nonylphenol on doublesex- and mab-3-related transcription factor 1 gene expression and vitellogenin mRNA induction of adult rare minnow (Gobiocypris rarus). Environ. Toxicol. Chem. 27, 196-205. 